\title{
大豆乳酸発酵食品のラットにおける胆汁酸排泄促進効果
}

\author{
高木尚紘 ${ }^{* 1}$, 北脇涼子*2, 西村侑子*1, 岩崎充弘 ${ }^{* 3}$, \\ 都築公子*3，堀内理恵 $* 4 ，$ 福田 滿 $* 28$ \\ *1 武庫川女子大学大学院生活環境学研究科 \\ *2 武庫川女子大学生活環境学部 \\ *3 マルサンアイ株式会社開発統括部 \\ *4 大阪夕陽丘学園短期大学
}

\section{Effect of Okara/Soymilk Fermented by Lactic Acid Bacteria on Fecal Bile Acid Excretion of Rats}

\author{
Naohiro Takagi*1, Ryoko Kitawaki*2, Yuko Nishimura*1, Mitsuhiro Iwasaki*3, \\ Kimiko Tsuzuki*3, Rie Horiuchi*4 and Mitsuru Fukuda ${ }^{* 2 \$}$ \\ ${ }^{* 1}$ Graduate School of Human Environmental Sciences, Mukogawa Women's University, \\ 6-46 Ikebiraki-cho, Nishinomiya, Hyogo 663-8558 \\ ${ }^{* 2}$ School of Human Environmental Sciences, Mukogawa Women's University, \\ 6-46 Ikebiraki-cho, Nishinomiya, Hyogo 663-8558 \\ *3 Marusan-Ai Co.,Ltd., 1 Aza-Arashita, Nikki-cho, Okazaki, Aichi 444-2193 \\ ${ }^{* 4}$ Osaka Yuhigaokagakuen Junior College, 7-72 Ikutamateramachi, \\ Tennoji-ku Osaka, Osaka 543-0073
}

\begin{abstract}
As okara ingestion suppresses the increase in plasma cholesterol level in rats, we attempted to effectively use okara as a functional food. Soymilk containing okara (okara/soymilk) fermented by lactic acid bacteria showed higher in vitro bile acid-adsorptive capacity than unfermented okara/soymilk. Lactic fermentation increased the alkali-stable polysaccharide content of okara/soymilk. Fecal bile acids and cecum content of rats fed fermented okara/soymilk were also increased. Moreover, lactic fermentation increased the propionic and butyric acid contents in the cecum. Alkali-stable polysaccharides generated by lactic fermentation were assumed to increase short-chain fatty acids in rat intestines and fecal bile acids. Alkaline treatment could extract bile acid-adsorptive compounds from fermented okara/soymilk, but decreased the adsorptive capacity of the extract. Protein was the main bile acid-adsorptive compound separated from fermented okara/soymilk, but no increase in bile acid-adsorptive capacity in the separated proteins was observed after lactic fermentation. Therefore, the increase in bile acid-adsorptive capacity appears to depend on alkali-stable insoluble polysaccharides generated by the lactic fermentation process.

(Received Apr. 15, 2008 ; Accepted Aug. 21, 2008)
\end{abstract}

Keywords : bile acid, lactic fermentation, okara, short-chain fatty acid, soymilk キーワード : 胆汁酸, オカラ, 豆乳, 乳酸発酵, 短鎖脂肪酸

大豆は昔から和食において多用されてきた食品素材であ る。大豆タンパク質には血中コレステロール濃度上昇抑制

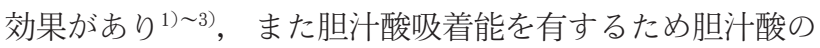
腸肝循環を抑制することで血清コレステロール濃度を低下 させる作用があると報告されている ${ }^{4)}$ ７)，大豆を豆腐や豆 乳に加工する過程で大量に発生するオカラの大部分は食品

*1 $\mathbf{T} 663-8558$ 兵庫県西宮市池開町 6-46

*2 $\mathbf{T} 663-8558$ 兵庫県西宮市池開町 6-46

*3 $\mathbf{T} 444-2193$ 愛知県岡崎市仁木町字荒下 1

${ }^{* 4} \mathbf{T} 444-2193$ 大阪府大阪市天王寺区生玉寺町 7-12

\&連絡先 (Corresponding author), senjuoka@mukogawa-u.ac.jp
素材として利用されることはほとんどなく産業廃棄物とし て処理されている。しかし，オカラには大豆タンパク質， 食物繊維やイソフラボン8) 等の機能性物質が多く含まれて いる．著者らは高コレステロール食摂取ラットにオカラを 投与することによって血漿コレステロール上昇抑制作用, 肝臓脂肪蓄積抑制作用を認めた ${ }^{9}$. このことからオカラに 残存する大豆タンパク質, 食物繊維, イソフラボン等は生 活習慣病予防に有効であると考えられる。このオカラを有 効利用する目的で豆乳之混合し植物性乳酸菌を用いて乳酸 発酵させ，ヨーグルト状食品を作製した．Kikuchi ら ${ }^{10)}$ に 
よると，豆乳のみをビフィズス菌を用いて乳酸発酵させる と粪中胆汁酸排泄は促進されなかったが, 荒ら ${ }^{11)}$ は豆乳を 乳酸菌で発酵させると糞中コレステロール排泄量が増加し たと報告している。しかし, 著者らはオカラおよび豆乳の 乳酸発酵物による胆汁酸の排泄促進効果を認めた ${ }^{12)}$. 著者 らはオカラ豆乳の乳酸発酵物による胆汁酸吸着作用を調 へ，動物実験における粪中胆汁酸排泄効果の原因について の知見を得て, さらに胆汁酸吸着物質が本乳酸発酵食品に 存在することを認めたので報告する。

\section{実 験 方 法}

\section{1. 実験材料}

実験に用いたオカラ豆乳乳酸発酵食品（以下発酵オカラ 豆乳）はオカラと豆乳を $1: 2$ (乾燥重量比) で混合し植物 性乳酸菌 (Lactobacillus delbruekii subsp. delbruekii 菌 株 SNC33）を用いて 15 時間発酵させた後, 凍結乾燥して 粉末状にしたものを使用した。

\section{2. 発酵オカラ豆乳の胆汁酸吸着試験}

胆汁酸吸着試験は Sugano $~^{13)}$ の方法を改変して行っ た. 脱脂した乾燥乳酸発酵才カラ豆乳粉末 $(5,10,50,100$ $\mathrm{mg}$ ）を $0.1 \mathrm{mM}$ の各種コール酸（コール酸, タウロコール 酸，グリココール酸）を含む $0.1 \mathrm{M} ト$ トス塩酸緩衝液（pH 7.4） $1.5 \mathrm{ml}$ に懸濁し $37^{\circ} \mathrm{C}$ で 2 時間反応させた. その後 13 $000 \times \mathrm{g}$ で 5 分間遠心分離した後, 上清を CENTRICUT （クラボウ, W-20）でろ過した。 ろ液中のコール酸濃度は 胆汁酸測定キット (和光純薬工業, 総胆汁酸テストワコー) を用いて酵素法で測定した。対照には未発酵の乾燥オカラ 豆乳粉末を用いて同様に試験し測定を行った。胆汁酸吸着 能は胆汁酸吸着率\%(吸着した胆汁酸量/元の胆汁酸量 $\times$ 100）で表示した.

\section{3. ラットの飼育条件}

5 週齢の Sprague-Dawley 系雄性ラット $(\mathrm{n}=21)$ （日本 クレア株式会社）を用いて 2 週間基準飼料として AIN-93 の組成の飼料 ${ }^{14)}$ で予備飼育の後, コントロール群 $(\mathrm{n}=7)$ には基準飼料, 未発酵才カラ豆乳群 $(n=7)$ および発酵才 カラ豆乳群 $(n=7)$ にはコントロール群飼料の $20 \%$ を 各々乾燥未発酵才カラ豆乳, 発酵才カラ豆乳で栄養組成及 びエネルギー量が同一になるように置換した飼料を 6 週間 与えた. ラットは個別に金網ケージに入れ, 室温 $23 \pm 1{ }^{\circ} \mathrm{C}$,

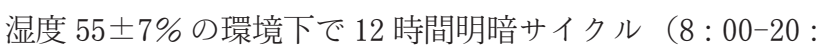
00）で自由摂食, 自由攝水させた。本動物実験は武庫川女 子大学動物実験指針に基づいて実施した.

\section{4. ラットにおける糞中胆汁酸排泄量の比較}

ラットを用いてコントロール群, 未発酵オカラ豆乳群お よび発酵オカラ豆乳群から採取した粪中胆汁酸は凍結乾燥 した粪を $70^{\circ} \mathrm{C}$ のタノール中で 1 時間抽出した後, 胆汁 酸測定キット（和光純薬工業, 総胆汁酸テストワコー）を 用いて酵素法で測定した。

\section{5. ラット盲腸内短鎖脂肪酸量の比較}

盲腸内短鎖脂肪酸量測定は吉本ら ${ }^{15)}$ の方法を改良して行っ た。盲腸内容物を 2 倍量の蒸留水に溶解し攪拌後, 13000 $\times \mathrm{g}$ で 30 分間遠心分離を行い, その上清をディスポーザ ブルフィルター（マイショリディスク W-3-2 東ソー株式会 社)でろ過した液を試料とし, 高速液体クロマトグラフィー （HPLC 装置，東ソー株式会社）で有機酸分析システムに よる分析を行った. 有機酸分析用カラム TSK gel OApak$\mathrm{P}$ プレカラム + TSK gel OApak-A カラム $(6.0 \mathrm{mmID} \times 4$ $\mathrm{cm}+7.8 \mathrm{mmID} \times 30 \mathrm{~cm}$ ), 電気伝導度検出器 CM8020（東 ソー株式会社）を使用した。溶離液には $0.1 \mathrm{mM} \mathrm{H}_{2} \mathrm{SO}_{4}$ を 用いて流速 $0.8 \mathrm{ml} / \mathrm{min}$ で溶出して検出した.

\section{6. アルカリ処理と無処理の糖質含量の比較}

未発酵オカラ豆乳と発酵オカラ豆乳を $0.1 \mathrm{M} \mathrm{NaOH}$ に 室温で 2 時間懸濁し, 中和, 透析後に凍結乾燥したものと 水に同様に懸濁し透析後凍結乾燥した粉末 $50 \mathrm{mg}$ につい て胆汁酸吸着活性を上述 2. の方法で測定し，また糖質含量 をフェノール硫酸法 ${ }^{16)}$ で測定した。

\section{7. 胆汁酸吸着物質の抽出}

発酵オカラ豆乳 $10 \mathrm{~g}$ に対して 20 倍量の $0.1 \mathrm{M} \mathrm{NaOH}$ を 用いて室温で 2 時間攪拌抽出し ${ }^{17)} ， 6700 \times \mathrm{g}$ で 20 分間遠 心分離後上清を採取した。この操作を 2 回繰り返した。集 めた上清と沈殿を中和し一昼夜透析した後, 凍結乾燥した 粉末 $50 \mathrm{mg}$ についてタウロコール酸を用いて胆汁酸吸着 試験を行った.さらに抽出画分（上清） $5 \mathrm{mg}$ にっいて Cellulofine GCL-2000 (生化学工業株式会社)（カラムサイ ズ : $1.5 \times 50 \mathrm{~cm}$, 流速 $0.3 \mathrm{ml} / \mathrm{min})$ によってゲルろ過クロ マトグラフィーを行った. クロマトグラフィー後の各フラ クションについて $220 \mathrm{~nm}$ でタンパク質を測定した。 ピー クが見られたフラクションを集めて中和, 透析した後凍結 乾燥し, その乾燥粉末 $50 \mathrm{mg}$ をタウロコール酸を用いて胆 汁酸吸着試験を行った。

\section{8. 統計処理}

各実験結果は平均土標準誤差 (mean土SE) で示した. 有意差の検定にはSPSS for Windows $12.0 \mathrm{j}$ を使用し, 2 群間の比較には $t$-test を行い, 3 群間の比較に Tukey の多 重比較検定を行い, $p$ 值が 0.05 未満のものを統計的に有意 とした。

\section{実験結果および考察}

\section{1. 乳酸発酵による胆汁酸吸着能の増加}

発酵オカラ豆乳とその未発酵物の胆汁酸吸着能を比較し た. Table 1 に示すように未発酵オカラ豆乳で見られた胆 汁酸吸着能は主に大豆夕ンパク質のもつ胆汁酸吸着能によ ると考えられる ${ }^{4)}$ ）（いずれの種類の胆汁酸においても未 発酵オカラ豆乳よりあ発酵才カラ豆乳において胆汁酸の吸 着率は増加していた。胆汁酸吸着率は試料濃度依存的に上 昇した。このことから乳酸発酵による新規胆汁酸吸着物質 
Table 1 Bile acid adsorption rate of unfermented and fermented okara/soymilk

Adsorption rate of bile acid $(\%)$

\begin{tabular}{llcccc}
\hline \hline \multirow{2}{*}{ Bile acid } & & \multicolumn{4}{c}{ Amount of okara/soymilk } \\
\cline { 3 - 6 } & & 5 & 10 & 50 & 100 \\
\hline \multirow{2}{*}{ Cholic acid } & Unfermented & $24.9 \pm 1.5$ & $29.1 \pm 10.8$ & $52.0 \pm 2.9$ & $61.2 \pm 0.4$ \\
& Fermented & $30.1 \pm 0.6$ & $35.5 \pm 6.9$ & $93.9 \pm 0.4^{* * *}$ & $97.9 \pm 0.5^{* * *}$ \\
\multirow{2}{*}{ Taurocholic acid } & Unfermented & $30.9 \pm 1.2$ & $41.0 \pm 1.6$ & $65.1 \pm 0.6$ & $73.5 \pm 0.3$ \\
& Fermented & $36.5 \pm 3.2$ & $44.6 \pm 2.1$ & $91.0 \pm 1.8^{* * *}$ & $97.4 \pm 0.2^{* * *}$ \\
\multirow{2}{*}{ Glycocholic acid } & Unfermented & $25.5 \pm 1.3$ & $28.0 \pm 1.7$ & $49.3 \pm 1.1$ & $62.4 \pm 1.8$ \\
& Fermented & $32.6 \pm 1.1^{*}$ & $35.7 \pm 2.7$ & $80.6 \pm 1.3^{* * *}$ & $93.6 \pm 0.8^{* * *}$ \\
\hline
\end{tabular}

Each value is expressed as the mean $\pm \mathrm{SE}(\mathrm{n}=3)$.

Statistical significance compared to unfermented okara/soymilk : ${ }^{*} \mathrm{p}<0.05$ and ${ }^{* * *} \mathrm{p}<0.005$

Table 2 Organic acid and short-chain fatty acid concentration in cecum content of rats fed a high-cholesterol diet

$\mathrm{mg} / \mathrm{g}$ cecum content

\begin{tabular}{lccccc}
\hline \hline & Lactic acid & Acetic acid & Propionic acid & Butyric acid & SCFA Total \\
\hline Control & $8.11 \pm 0.31$ & $4.4 \pm 0.47^{\mathrm{a}}$ & $1.27 \pm 0.29$ & $0.86 \pm 0.09^{\mathrm{a}}$ & $14.63 \pm 0.87^{\mathrm{a}}$ \\
Unfermented & $8.25 \pm 0.68$ & $6.26 \pm 0.29^{\mathrm{ab}}$ & $1.73 \pm 0.16$ & $2.01 \pm 0.22^{\mathrm{b}}$ & $18.53 \pm 0.89^{\mathrm{b}}$ \\
Fermented & $7.81 \pm 0.71$ & $5.23 \pm 0.28^{\mathrm{b}}$ & $1.88 \pm 0.09$ & $2.22 \pm 0.12^{\mathrm{b}}$ & $17.15 \pm 0.89^{\mathrm{ab}}$ \\
\hline
\end{tabular}

Each value is expressed as the mean $\pm \mathrm{SE}(\mathrm{n}=7)$.

Values in a column not sharing a common superscript letter are significantly different at $\mathrm{p}<0.05$.

の生成が示唆された。

\section{2. 䔬中胆汁酸含有量の比較}

$1 \mathrm{~g}$ 粪あたりの胆汁酸排泄量はコントロール群で $27.4 \pm$ $8.8 \mathrm{mg}$ に対して未発酵オカラ豆乳群で $45.4 \pm 5.0 \mathrm{mg}$ で あった. コントロール群に比較して発酵オカラ豆乳群では $54.2 \pm 13.2 \mathrm{mg}$ となり有意に高值であった（Fig. 1).

\section{3. 盲腸内短鎖脂肪酸量の比較}

オカラ豆乳, 乳酸発酵オカラ豆乳を与えると盲腸内容物 重量がコントロール群の $2.3 \pm 0.5 \mathrm{~g}$ に比べて, それぞれ 3.2 $\pm 0.9 \mathrm{~g}, 3.5 \pm 0.5 \mathrm{~g}$ に増加する傾向にあった. 盲腸 $\mathrm{pH}$ はコ ントロール群の $7.1 \pm 0.3$ に比べてオカラ豆乳群，乳酸発酵 オカラ豆乳群ではそれぞれ $6.7 \pm 0.4,6.9 \pm 0.4$ に低下する傾 向にあった. 盲腸内容物の有機酸と短鎖脂肪酸の総量はコ ントロール群に比較してオカラ豆乳, 乳酸発酵オカラ豆乳 で増加傾向であり, プロピオン酸濃度はコントロール群の $1.27 \pm 0.29 \mathrm{mg} / \mathrm{g}$ から $1.73 \pm 0.16 \mathrm{mg} / \mathrm{g}, 1.88 \pm 0.09 \mathrm{mg} / \mathrm{g}$ にそれぞれ増加傾向で, 酪酸濃度は $0.86 \pm 0.09 \mathrm{mg} / \mathrm{g}$ から $2.01 \pm 0.22 \mathrm{mg} / \mathrm{g}, 2.22 \pm 0.12 \mathrm{mg} / \mathrm{g}$ にそれぞれ有意に増加 した（Table 2)。発酵オカラ豆乳による盲腸重量増加の原 因は腸内微生物が利用可能な多糖類が乳酸発酵過程で生成 し，菌体増殖と短鎖脂肪酸を生じたと推定される ${ }^{18) 199}$.

\section{4. アルカリ処理の有無による糖質含量と胆汁酸吸着量 の比較}

未発酵, 発酵オカラ豆乳を $0.1 \mathrm{M} \mathrm{NaOH}$ に懸濁後, 中 和，透析を行い凍結乾燥したもの，対照として蒸留水に懸

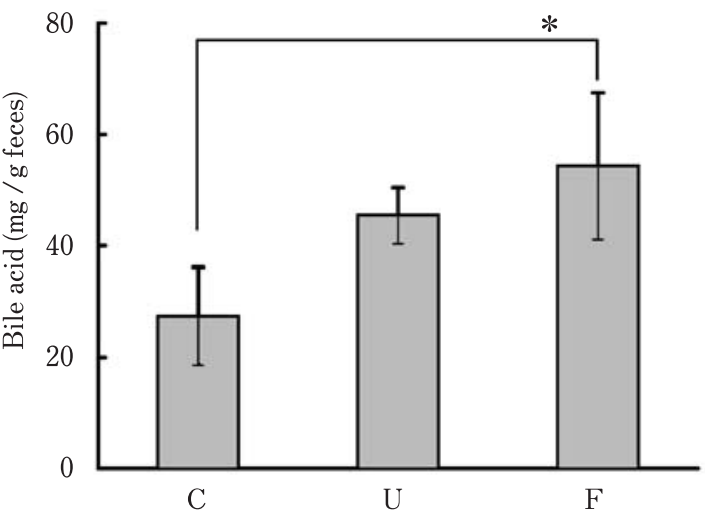

Fig. 1 Effect of unfermented and fermented okara/ soymilk on bile acid concentration in feces of rats fed a high-cholesterol diet

C, control; U, unfermented okara and soymilk; F, fermented okara and soymilk.

Each value is expressed as the mean $\pm \mathrm{SE}$ of 7 rats. An asterisk denotes significant difference from the control. ${ }^{*}: \mathrm{p}<0.05$.

濁後，透析を行い凍結乾燥したもののそれぞれの糖質含量 を測定したところ，未発酵オカラ豆乳ではアルカリ処理に よって透析膜内に残る糖含量が減少した。発酵才カラ豆乳 では未発酵オカラ豆乳に比較してアルカリ処理による糖含 量の低下が少なかったので, 乳酸発酵で生成した多糖類は アルカリ処理に安定な多糖類（細菌細胞壁 ${ }^{17)}$ ・分泌物）で 
Table 3 Carbohydrate content in okara/soymilk treated with or without $0.1 \mathrm{M} \mathrm{NaOH}$ solution

\begin{tabular}{ccc}
\hline \hline & \multicolumn{2}{c}{ Carbohydrate content $\mathrm{mg} / \mathrm{g}$} \\
\cline { 2 - 3 } & Unfermented & Fermented \\
\hline Not treated & $193 \pm 4.0$ & $199 \pm 1.1$ \\
Alkali treated & $174 \pm 8.5$ & $193 \pm 6.0$ \\
\hline
\end{tabular}

Each value is expressed as the mean $\pm \mathrm{SE}(\mathrm{n}=3)$.

Table 4 Bile acid adsorption rate of unfermented and fermented okara/soymilk treated with or without $0.1 \mathrm{M} \mathrm{NaOH}$ solution

\begin{tabular}{lcc}
\hline \hline & \multicolumn{2}{c}{ Adsorption rate of bile acid (\%) } \\
\cline { 2 - 3 } & Unfermented & Fermented \\
\hline Not treated & $55.7 \pm 2.5$ & $89.2 \pm 3.6^{* * *}$ \\
Alkali treated & $53.0 \pm 2.0$ & $90.5 \pm 5.1^{* * *}$ \\
\hline
\end{tabular}

Each value is expressed as the mean $\pm \mathrm{SE}(\mathrm{n}=3)$.

Statistical significance compared to unfermented okara/ soymilk : ${ }^{* * *} \mathrm{p}<0.005$

Table 5 Bile acid-adsorption rate of alkaline extract of okara/soymilk

\begin{tabular}{lcl}
\hline \hline & \multicolumn{2}{c}{ Adsorption rate (\%) } \\
\cline { 2 - 3 } & Unfermented & Fermented \\
\hline okara/soymilk & $67.9 \pm 2.7$ & $89.2 \pm 0.5^{* * *}$ \\
Extract & $60.7 \pm 10.1$ & $70.6 \pm 2.6$ \\
\hline
\end{tabular}

Each value is expressed as the mean $\pm \mathrm{SE}(\mathrm{n}=3)$.

あったと示唆される（Table 3)，このアルカリ処理に安定 な多糖類が乳酸発酵で増加し, アルカリ処理後屯胆汁酸吸 着能を維持したと示唆される (Table 4).

\section{5. 未発酵物及び発酵物のアルカリ抽出}

未発酵, 発酵才カラ豆乳からの $0.1 \mathrm{M} \mathrm{NaOH}$ による有機 物の抽出率はそれぞれ $55 \%, 52 \%$ となり，両者の間に差は 認められなかった。 また得られた抽出画分についての胆汁 酸吸着活性はアルカリ抽出前では未発酵才カラ豆乳と比較 して発酵オカラ豆乳では著しく高い胆汁酸吸着率が認めら れたが，アルカリ抽出画分では発酵オカラ豆乳の吸着率が 減少し両者の吸着率の差は縮小した（Table 5)。乳酸発酵 物のアルカリ抽出画分の胆汁酸吸着活性が減少したので, 胆汁酸吸着性物質はアルカリ処理後む不溶性画分に残存す ると示唆される.

抽出画分をゲルろ過クロマトグラフィーに供したところ 未発酵, 発酵オカラ豆乳ともに $170 \mathrm{kDa}, 48 \mathrm{kDa}$ にピーク が見られた (Fig. 2).この二つのフラクションをそれぞれ 集めて中和, 透析を行い凍結乾燥後, 胆汁酸吸着活性を測 定したところ未発酵と発酵オカラ豆乳の間に吸着活性の差 はほとんど見られなくなった（Table 6)。また，乳酸発酵

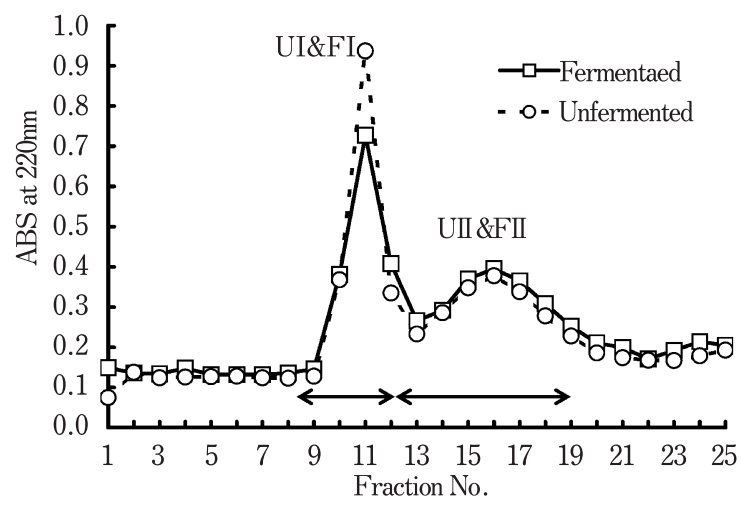

Fig. 2 Cellulofine GCL-2000 $(1.5 \times 50 \mathrm{~cm})$ gel filtration of fraction extracted from fermented and unfermented okara/soymilk, respectively

column : $1.5 \times 50 \mathrm{~cm}$

1 fraction $=3 \mathrm{ml}$ elution speed $: 0.8 \mathrm{ml} / \mathrm{min}$

Table 6 Bile acid-adsorption rate in fractions separated by gel filtration

\begin{tabular}{lcc}
\hline \hline & \multicolumn{2}{c}{ Adsorption rate $(\%)$} \\
\cline { 2 - 3 } & Unfermented & Fermented \\
\hline Fraction I & 52.4 & 64.1 \\
Fraction II & 44.7 & 42.7 \\
\hline
\end{tabular}

による大豆タンパク質組成にも变化がほとんど認められな かったので20), 未発酵オカラ豆乳と発酵才カラ豆乳の胆汁 酸吸着活性の差異は大豆夕ンパク質に基づくものではない と示唆される. オカラ豆乳の乳酸発酵による胆汁酸吸着能 増加の原因は乳酸発酵過程で新たに生成したアルカリに安 定な不溶性多糖類と推定された。

以上の結果から，オカラ豆乳の乳酸発酵によって生じた 多糖類は, 腸内で短鎖脂肪酸の生成を促進する効果をむつ 之同時に，強い胆汁酸吸着活性に基づく糞中胆汁酸排泄効 果の原因となると考えられた。

要 約

オカラ豆乳混合物は乳酸発酵するとアルカリに安定な多 糖類が若干増加し, 胆汁酸吸着能が増加した。乳酸発酵才 カラ豆乳をラットに投与すると未発酵オカラ豆乳に比較し て糞中胆汁酸量と盲腸重量は増加した。また，乳酸発酵才 カラ豆乳摂取によりラット盲腸内容物のプロピオン酸と酪 酸量が増加した。乳酸発酵で生成したアルカリに安定な多 糖類が腸内で微生物によって短鎖脂肪酸に变化したと推定 される。

胆汁酸吸着物質は $0.1 \mathrm{M} \mathrm{NaOH}$ 溶液で発酵オカラ豆乳 から抽出可能であったが，アルカリ抽出後に吸着能が低下 した。また，抽出した胆汁酸吸着物質をゲルろ過クロマト グラフィーで分離すると吸着物質の主成分はタンパク質で 
あったが，未発酵物と乳酸発酵物の間の吸着能の差は減少

した。 オカラ豆乳混合物の乳酸発酵による胆汁酸吸着能増 加の原因は主に乳酸発酵過程で生成するアルカリに安定な 不溶性多糖類と推定された。

\section{文献}

1) Nagata, Y., Ishiwaki, N. and Sugano, M., Studies on the mechanism of antihypercholesterolemic action of soy protein and soy protein-type amino acid mixtures in relation to the casein counterparts in rats, J. Nutr., 112, 1614-1625 (1982).

2) Tanaka, K. and Sugano, M., Effects of modification of the arginine/lysine ratio of dietary proteins on absorption and turnover of cholesterol in rats. Agric. Biol. Chem., 531, 1351-1356 (1989).

3) Andereson, J.W., Johnstone, B.M. and Cook-Newell, M. E., Meta-analysis of the effects of soy protein intake on serum lipids. N. Engl. J. Med., 333, 276-282 (1995).

4) Iwami, K., Sakakibara, K. and Ibuki, F., Involvement of post-digestion 'Hydrophobic' peptides in plasma cholesterol-lowering effect of dietary plant proteins. Agric. Biol. Chem., 50, 1217-1222 (1986).

5) Higaki, N., Sato, K., Suda, H., Suzuka, T., Komori, T., Saeki, T., Nakamura, Y., Ohtsuki, K., Iwami, K. and Kanamoto, R., Evidence for the existence of a soybean resistant protein that captures bile acid and stimulates its fecal excretion. Biosci. Biotech. Biochem., 70, 28442852 (2006).

6) Makino, A., Nakashima, H., Minami, K., Moriyama, R. and Takao, S., Bile acid-binding protein from soybean seed : isolation, partial characterization and insulin-stimulating activity. Agric. Biol. Chem., 52, 803-809 (1988).

7) Fukui, K., Tachibana, N., Wanezaki, S., Tsuzaki, S., Takamatsu, K., Yamamoto, T., Hashimoto, Y. and Shimoda, T., Isoflavone-free soy protein prepared by column chromatography reduces plasma cholesterol in rats. J. Agric. Food Chem., 50, 5717-5721 (2002).

8) O'Toole, D.K., Characteristics and use of okara, the soybean residue from soy milk production - A review. J. Agric. Food Chem., 47, 363-371 (1999).

9）福田 滿, 杉原好枝, 伊藤みどり, 堀内理恵, 浅尾弘明, 才 カラがラットの血中及び肝臟脂質濃度に及ぼす影響, 食科 工, 53, 195-199 (2006).
10) Kikuchi-Hayakawa, H., Onodera, N., Matsubara, S., Yasuda, E., Caonan, O., Takahashi, R. and Ishikawa, F., Effect of soy milk and bifido- bacterium fermented soy milk on lipid metabolism aged ovariectomized rats. Biosci. Biotech. Biochem., 62, 1688-1692 (1998).

11）荒 勝俊, 大辻一也, 川合修次, 大久保一良, 発酵豆乳の脂 質代謝および腸内フローラに及ぼす影響, 食科工，48，807815 (2001).

12）北脇涼子, 高木尚紘, 岩崎充弘, 浅尾弘明, 岡田早苗, 福田 滿, 乳酸発酵させたオカラ豆乳のラット血漿コレステロー 儿低下作用，食科工，54，379-382（2007）.

13) Sugano, M., Goto, S., Yamada, Y., Yoshida, K., Hashimoto, Y., Matsuo, T. and Kimoto, M., Cholesterollowering activity of various undigested fraction of soybean protein in rats. J. Nutr., 120, 977-985 (1990).

14) Reeves, P.G., Nielsen, F.H. and Fahey, G.C. Jr., AIN-93 purified diets for laboratory rodents : final report of the American institute of nutrition Ad Hoc Writing Committee on the reformulation of the AIN-76A rodent diet. J. Nutr., 123, 1939-1951 (1993).

15）吉本朋子, 佐藤一精, 脱脂大豆粉から調製した豆乳ヨーグ ルト様食品の特性，食科工，48，906-912（2001）.

16） Dubois, M., Gilles, K.A., Hamilton, J.K., Rebers, P.A. and Smith, F., Colorimetric method for determination of sugars and related substances. Anal. Chem., 28, 350-356 (1956).

17) Ikawa, M., The partial chemical degradation of the cell walls of Lactobacillus plantarum, Streptococcus faecalis and Lactobacillus casei. J. Biol. Chem., 236, 1087-1092 (1961).

18) Noack, J., Dongowski, G., Hartmann, L. and Blaut, M., The human gut bacteria Bacteroides thetaiotaomicron and Fusobacterium varium produce putrescine and spermoidine in cecum of pectin-fed gnotobiotic rats. $J$. Nutr., 130, 1225-1231 (2000).

19) Demingé, C. and Rémésy, C., Stimulation of absorption of volatile fatty acids and minerals in the cecum of rats adapted to a very high fiber diet. J, Nutr., 115, 53-60 (1985).

20）高木尚紘, 北脇涼子, 浅尾弘明, 岩崎充弘, 福田 滿, 新規 乳酸菌を用いたおから・豆乳発酵食品の成分特性, 武庫川 女子大紀要 (自然科学), 54, 31-35 (2006).

(平成 20 年 4 月 15 日受付，平成 20 年 8 月 21 日受理) 